\author{
Case Study
}

\title{
MANAGEMENT OF BANDHYATAVA (INFERTILITY) BY SODHAN FOLLOWED BY SHAMAN CHIKITSA: A CASE REPORT
}

\section{Renu Yadav $^{1 *}$, Soni Kapil², Anil Bhardwaj ${ }^{3}$}

${ }^{*}$ PG Scholar, ${ }^{2}$ Reader, Department of Prasuti Tantra Evum Stree Roga, ${ }^{3}$ Reader, Department of Panchkarma, Rajiv Gandhi Govt. Post Graduate Ayurvedic College \& Hospital, Paprola, Himachal Pradesh, India.

\section{Article info \\ Article History: \\ Received: 18-05-2021 \\ Revised : 01-06-2021 \\ Accepted: 10-06-2021 \\ Published:25-08-2021 \\ KEYWORDS: \\ Vandytava, \\ Sodhan, Shaman, \\ Doshas, Dushyas, \\ PCOS.}

\begin{abstract}
As per Ayurveda Vandhyatva occurs due to the vitiation of Vata Dosha which affects basic four constituents of Garbha sthapana. In modern science Infertility is described as an inability to conceive despite unprotected sex for duration of one year or more and PCOS is a major causative factor behind it. PCOS results in deterioration of female reproductive health which leads to infertility. In Ayurveda Samhithas, vast range of treatment methods are described. The basic aim in Ayurveda is to correct Ritu, Kshetra, Ambu and Beeja, the four basic factors for infertility by Shamana and Shodhan Chikitsa. Panchkarma provides best efficacy because it helps in balancing Doshas and Dushyas. Uttarbasti is also indicated for infertility which helps in detoxification of reproductive tract and balancing Vata Dosha, finally helps in retaining Garbha. In this case report importance of Sodhan Chikitsa before Shaman Chikitsa in case of infertility is emphasized.
\end{abstract}

\section{INTRODUCTION}

Procuring a baby is the lifetime dream of every individual in the society. But now a days, infertility rate is rising among the women in the reproductive age group. As per Ayurveda, a normal conception takes place when Ritu, Kshetra, Ambu and Beeja (the four factors) unite in their normalcy and offspring is produced [1]. In Ayurvedic terminology, Vandhyatva (infertility) is failure to give birth to a baby or experiencing Garbha Strava (repeated abortion) or Mrutvatsa (still births) [2].

In the current scenario of massive advancements in the field of medicine and technology, infertility is the problem that has been continued since ages. As a well-known social stigma is attached to it. Acharya Charaka has explained the woman is the origin of progeny [3].

\begin{tabular}{|l|l|}
\hline \multicolumn{3}{|c|}{ Access this article online } \\
\hline Quick Response Code & \\
\hline &
\end{tabular}

In Ayurvedic texts infertility explained as Vandhyatva which is due to Vata Dosha and mentioned in Rasdhatu Pradoshaja Vikar [4]. It is considered as Yonivyapad as per Sushruta Samhita while Charka explained it as a consequence of abnormality of bija (Pradushta Garbhasaya Bija Bhaga of shonita) ${ }^{5}$. Madhavkara have quoted Vandhya in Vimsati Yonivyapat. Acharya Kashyapa has mentioned Vandhyatva as one of the 80 disorders of Vata. The major elements involved for a healthy progeny is Ritu, Kshetra, Ambu and Beeja and any abnormality of these factors can lead to infertility.

Infertility is commonly increasing problem which gynecologists have to face in day today practice. It disturbs social and family life of a woman and affects her mental and physical health. Woman of reproductive age who has not conceived after one year of unprotected vaginal sexual intercourse is defined as infertile. Its common cause appears to be ovulation disorder along with H-P-O axis disturbance and disturbed menstrual cycle. The common cause of infertility as per modern science depicted in figure 

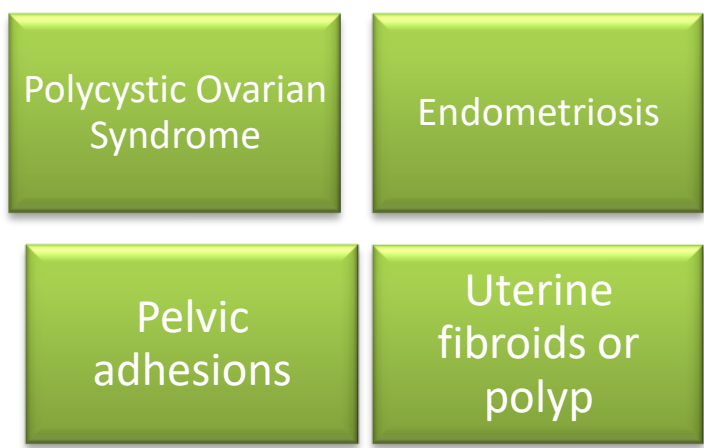

\section{Pelvic}

adhesions fibroids or

polyp
PCOS is a leading cause which leads to infertility due anovulation or oligo ovulation. Polycystic ovarian syndrome is a common disorder in today scenario. In Ayurveda PCOS is not described as a different disease. The clinical features and etiopathogenesis may be correlated to different gynecological disorders. In classic texts gynecological problems can be incorporated in Yonivyapad and Aartav Dushti. Yonivyapad is mainly due to Vata or we can say there is no existence Yonivyapad without vata ${ }^{5}$. Based on these principles PCOS and infertility can be considered as predominantly Vata Dushti associated with Kapha and Pitta Dushti. PCOS generally associated with increasing obesity so it involves Dhatvagnimandya. As all female reproductive organs lie in pelvic area thus Apan Vayu governs all the physiological functions. So, the management in PCOS should be targeted at Agnideepana, Pachana, Vatanulomna.

PCOS associates with menstrual disorders like irregular menses, oligomenorrhea or amenorrhea. It is a complex disorder comprising of anovulation, hyperandrogenism and polycystic ovaries. It is a disorder of the endocrine system caused by hormonal imbalance. It is basically interfering in growth of ovarian follicle.

\section{MATERIAL AND METHODS Description of Patient}

A female patient aged 29 yeasr presented to OPD of RGG PG Ayurvedic hospital Paprola with the complaint of inability to conceive in the last four years. She is married for the past 5 years and living with husband regularly. She also had complaint of menstrual irregularity in the past 5 years. She had complaint of increased interval of menstrual cycle about 40-45 days. Along with it she had heavy menses with duration of 10-15 days. Ultrasonography suggested normal uterus with polycystic ovarian disease. She has been treated for PCOS since 2019 by certain Ayurvedic oral therapy but she didn't conceive therefore she has been motivated for Ayurvedic Sodhana Chikitsa with oral medication to achieve the conception. The semen analysis of partner was also abnormal. His active motility of sperm count is less than normal thus, because of borderline report of semen analysis of male partner he was also advised for Sodhan followed by Vajikaran chikitsa.

\section{Menstrual History}

- Age of Menarche -13 years

- Duration - 10- 15 days

- Interval - 40-45 days

- Amount - moderate to heavy

- Associated symptoms - pain, smell and clots during menstrual period not present

\section{Contraceptive History: Nil}

\section{Family History}

No family history of DM, HTN, TB and thyroid dysfunction. No history of exposure to radiation, any toxin or chemical agent.

Examination of Patient

\begin{tabular}{|l|l|}
\hline Examination & Results \\
\hline Weight & $63 \mathrm{~kg}$ \\
\hline Height & $160 \mathrm{~cm}$ \\
\hline BMI & $18.3 \mathrm{~kg} / \mathrm{m}^{2}$ \\
\hline BP & $110 / 68 \mathrm{~mm}$ of hg \\
\hline Pulse Rate & $88 \mathrm{bpm}$ \\
\hline Breast Examination & NAD \\
\hline P/A & Soft, nontender \\
\hline P/S & Cervix- Normal size, regular, thick white discharge present \\
\hline P/V & $\begin{array}{l}\text { Cervix-Normal size, regular, firm, mobile, no motion tenderness } \\
\text { Uterus- N.S, A.V, mobile nontender } \\
\text { Fornix - clear nontender }\end{array}$ \\
\hline
\end{tabular}


Ashtavidha Pariksha

\begin{tabular}{|l|l|}
\hline Parameter & Results \\
\hline Nadi & 88bpm \\
\hline Mala & Once a day \\
\hline Mutra & 3-4 times/day, Peetabh shwet varna \\
\hline Jivha & Anavritta \\
\hline Shabda & Spashta \\
\hline Sparsha & Anushna sheet \\
\hline Druk & Nirmal \\
\hline Akriti & Madhyam \\
\hline
\end{tabular}

Dashvidha Pariksha

\begin{tabular}{|l|l|}
\hline Parameter & Results \\
\hline Prakruti & Pitta Pradhan vata \\
\hline Vikriti & Aartav vaha sansthangat \\
\hline Sara & Raktasara \\
\hline Samhanan & Madhyam \\
\hline Praman & Madhyam \\
\hline Satmya & Sarav rasa \\
\hline Satva & Madhyam \\
\hline Ahar Shakti & Madhyam \\
\hline Vyayam Shakti & Madhyam \\
\hline Vaya & Madhyavastha \\
\hline
\end{tabular}

Investigations Before Treatment

\begin{tabular}{|l|l|}
\hline Parameter & Results \\
\hline Husband's Semen Analysis & WNL \\
\hline Total count & 68 million \\
\hline Active & $45-65.5$ \\
\hline Sluggish & $25-35 \%$ \\
\hline Abnormal forms & Up to 35\% \\
\hline Pus cells & $6-10 / \mathrm{HPF}$ \\
\hline
\end{tabular}

\begin{tabular}{|l|l|}
\hline USG Results \\
\hline Uterus & $\mathrm{N} . \mathrm{S}(5.1 * 4.7 * 3.2 \mathrm{~cm})$ \\
\hline ET & $6 \mathrm{~mm}$ \\
\hline Right ovary & $6.5 \mathrm{cc}$ \\
\hline Left ovary & $9.0 \mathrm{cc}$ \\
\hline B/L ovaries shows multiple follicles seen in periphery \\
S/O B/L polycystic ovarian disease \\
\hline
\end{tabular}

Investigations of Patient

\begin{tabular}{|l|l|}
\hline Investigation & Result \\
\hline $\mathrm{BT}$ & $1 \mathrm{~min} 45 \mathrm{sec}$ \\
\hline $\mathrm{CT}$ & $6 \mathrm{~min} 00 \mathrm{sec}$ \\
\hline S. Prolactin & $5.76 \mathrm{ng} / \mathrm{ml}$ \\
\hline $\mathrm{T}_{3}$ & $3.21 \mathrm{pg} / \mathrm{ml}$ \\
\hline $\mathrm{T}_{4}$ & $1.03 \mathrm{ng} / \mathrm{dl}$ \\
\hline $\mathrm{TSH}$ & $4.059 \mathrm{uIU} / \mathrm{ml}$ \\
\hline
\end{tabular}


Int. J. Ayur. Pharma Research, 2021;9(7):35-40

\begin{tabular}{|l|l|}
\hline Mantoux test & Negative \\
\hline Total cholesterol & $182 \mathrm{mg} / \mathrm{dl}$ \\
\hline H.D.L Cholesterol & $41 \mathrm{mg} / \mathrm{dl}$ \\
\hline Triglyceride(f) & $126 \mathrm{mg} / \mathrm{dl}$ \\
\hline LDL & $116 \mathrm{mg} / \mathrm{dl}$ \\
\hline VLDL & $25 \mathrm{mg} / \mathrm{dl}$ \\
\hline LH & $9.6 \mathrm{miu} / \mathrm{ml}$ \\
\hline FSH & $5.5 \mathrm{miu} / \mathrm{ml}$ \\
\hline
\end{tabular}

\begin{tabular}{|l|l|}
\hline Investigation & Results \\
\hline Blood group & A positive \\
\hline $\mathrm{Hb}$ & $12.8 \mathrm{~g} / \mathrm{dl}$ \\
\hline RBS & $94 \mathrm{mg} / \mathrm{dl}$ \\
\hline ESR & $19 \mathrm{~mm}$ fall after $1 \mathrm{hr}$ \\
\hline TSB & $0.5 \mathrm{mg} / \mathrm{dl}$ \\
\hline DSB & $0.2 \mathrm{mg} / \mathrm{dl}$ \\
\hline SGOT & $20 \mathrm{IU} / \mathrm{L}$ \\
\hline SGPT & $22 \mathrm{IU} / \mathrm{L}$ \\
\hline B. Urea & $23 \mathrm{mg} / \mathrm{dl}$ \\
\hline S. Creatinine & $0.7 \mathrm{mg} / \mathrm{dl}$ \\
\hline S. Uric acid & $3.3 \mathrm{mg} / \mathrm{dl}$ \\
\hline HIV & $\mathrm{NR}$ \\
\hline VDRL & $\mathrm{NR}$ \\
\hline HbSAg & $\mathrm{NR}$ \\
\hline
\end{tabular}

Treatment

Treatment plan for female patient

\begin{tabular}{|l|l|}
\hline Sodhan & Shamana \\
\hline - Vaman with Madanphala churn & $\bullet \quad$ Pushpdhanva rasa \\
- Virechna with Trivrit & $\bullet \quad$ Shtpushpa churna \\
- Asthapan basti with Dashmool trivrit kwath & $\bullet \quad$ Mishreya churna \\
- Uttarbasti with Phala ghrita & \\
\hline
\end{tabular}

Treatment plan for male patient

\begin{tabular}{|c|c|}
\hline Sodhan & Shamana \\
\hline - Vaman with Madanphala churn & $\bullet$ Cap Kapikachhu \\
- Virechna with Trivrit churn & $\bullet \quad$ Cap Cora Q \\
& $\bullet \quad$ Cap Shilajatu \\
\hline
\end{tabular}

\section{Sodhana chikitsa protocol for both partners}

Deepana Pachana: Panchkola churna 3gm twice a day given for 5 days before food with luke warm water.

Abhyantara Snehapana: done with Shuddh Go Ghrita for six days in Arohana krama (Escalating dose), started with $50 \mathrm{ml}$.

- First Day - 50ml

- Second Day - $100 \mathrm{ml}$

- Third Day - $150 \mathrm{ml}$

- Fourth Day - 200ml

- Fifth Day - 250ml
Samyak Snigdha lakshana are observed on $5^{\text {th }}$ day, like Adhasthat Sneha Darshana, Deeptagni, Snigdha varchas.

Vamana

On $6^{\text {th }}$ day Kaphavardhak Aahara and vihara was given to patient. On $7^{\text {th }}$ day after Sarvang Abhyanga and Swedena, Yavagu and Ksheer pan was done and Vamak yoga was given. Uttama Sudhi was observed with 6 Vega of Vamana and bile is observed in the vomitus. After it Sansarjan karma for 7 days was done. 


\section{Virechna}

Again, Snehpan start with $30 \mathrm{ml}$ of Goghrita on $5^{\text {th }}$ days and maximum dose was $150 \mathrm{ml}$. Smayak Sinagdh Lakshan was observed on $5^{\text {th }}$ day. $6^{\text {th }}$ day taken as vishrama kala and doshoutkleshak aahar vihara was given. On 7th day after Sarvang Abhayanga and Swedena Virechak yoga was given and Madyam Sudhi was observed. After it Sansarjana karma was followed for 5 days and then patient comes to normal diet. After it Sanshman Chikitsa was given to male partner meanwhile Bastikaram was planned for female.

\section{Basti Karma}

Then Basti karma was planned after clearance of menses.

\begin{tabular}{|l|l|}
\hline $\begin{array}{l}\text { Day from } \\
\text { menstruation }\end{array}$ & Basti \\
\hline $4^{\text {th }}$ day & Aasthapana followed by Uttar Basti \\
\hline $5^{\text {th }}$ day & Aasthapana followed by Uttar Basti \\
\hline $6^{\text {th }}$ day & Aasthapana followed by Uttar Basti \\
\hline
\end{tabular}

Then after all these procedure in next cycle couple advised for sanshman chikitsa with yoga and exercise and a healthy diet regularly.

\section{Shaman Chikitsa protocol \\ For female patient}

- Pushpdhanva Rasa
Key ingredients - Rasasindoor, Naga Bhasma, Vanga Bhasma, Loha Bhasma, Abhraka Bhasma

Dose 125 mg BD

- Shtpushpa Churna

Dose 3gm BD with water

- Mishreya Churna

Dose 3gm with water

\section{For male patient}

- Cap Kapikachhu (Kapikachhu extract) Dose (250 mg) 1 BD

- Cap Shilajatu (500mg) 1BD

- Cap Cora Q 10

Key ingredient - Co-enzyme Q10, Grape seed extract, lycopene with Multi- vitamin \& Multi Mineral Capsule

Dose - 1cap BD

In the same cycle in which oral medication advised to the female patient, graafian follicular study was done and the couple is advised to try for conception, guided by graafian follicular report in the fertile period

\section{RESULT}

After Sodhan Chikitsa in next cycle along with oral Ayurvedic drugs patient got normal ovulation and achieved conception.

Investigation after treatment

Follicular Study: started from $8^{\text {th }}$ day of menstrual cycle.

Figure 1: Graffian follicular study

\begin{tabular}{|l|l|l|l|l|}
\hline Day of Ovulation & Right Ovary & Left Ovary & $\begin{array}{l}\text { Endometrial } \\
\text { Thickness }\end{array}$ & Free Fluid \\
\hline $8^{\text {th }}$ & No dominant follicle & $14 \times 10 \mathrm{~mm}$ & $6 \mathrm{~mm}$ & Nil \\
\hline $10^{\text {th }}$ & No dominant follicle & $16 \times 13 \mathrm{~mm}$ & $6 \mathrm{~mm}$ & Nil \\
\hline $12^{\text {th }}$ & No dominant follicle & No dominant follicle & $8 \mathrm{~mm}$ & Mild free fluid seen \\
\hline Post Ovulation & & & & \\
\hline
\end{tabular}

In the following cycle the patient missed the period and advised USG to confirm the pregnancy.

\section{Result of sonography after treatment}

A single live intrauterine pregnancy seen with gestational sac

Gestational sac appears normal

Yolk sac seen

Cardiac activity appears normal

GA -7 weeks 6 days

CRL- $15 \mathrm{~mm}$

\section{DISCUSSION}

The principal therapies in Ayurveda can be divided in two parts i.e., Sodhan and Shaman Chikitsa which is helpful in infertility with anovulation and PCOS. The result strengthens the role of Ayurveda treatment in infertility and PCOS. In this case Charak
Chikitsa sutra for Vajikarana has been followed Charaka stated that before administration of Vajikarana therapy purification should be done so that Vitiated Doshas and toxins are removed from the body and blocked channels are opened [7]. This leads to increased bio-availability of Vajikarana drugs for beneficial results. As in this case the patient was treated by Shaman therapy for Vandhyatava in the last 4 years and she was taking pure Ayurvedic management for the same without any positive outcome. By following above guidelines of Charaka for Vajikarana Chikitsa ultimately the conception was achieved in this case. By doing Sodhan (Vaman and Virechna) we detoxify the body or we can say it is helpful in Srotosodhan through pacifying the Doshas Kapha and Pitta respectively. In Samprapti of PCOS there is Agnimandya ApanVayu sang, Vata Dushti and Dhatu Kshaya. Thus, by Sansodhan we make its 
Vighttan by doing Vatashaman and Vataanuloman. According to Acharyas basti is beneficial for Yonivyapad [8]. By Kashyapa Samhita Kalpa Sthan for Virechana it is mentioned that it improves the efficacy of Beeja ${ }^{[9]}$ (Bejam Bhavtai Karmukam)

The main principal of Basti treatment is to clear obstruction in pelvis, regulate menstrual cycle and normalize metabolism. Basti works on whole body after entering into Pakvashaya or Guda. It exerts local as well as systemic effects. Basti helps in normalizing the Apana Vata function and also helpful in correction of Agni Dushti leading to regulation of Rajah pravriti and Bija Nirmana.

Uttar Basti is the most effective in gynecological disorders as it directly works on Aartava Vaha Srotos, pacifies vitiated Apan Vayu and improves follicular maturity.

Thus, due to Samprapti Vighhatan by this Sodhana treatment followed by shamana yoga protocol the proper ovulation and finally the conception is achieved in this case. In Shudh sharir vajikarana treatment became more efficacious. Therapy showed highly significant result in treatment of infertility.

\section{CONCLUSION}

In case of infertility, we can achieve better success rate if we follow the guideline mentioned by Charka i.e., Sansodhan followed by Vajikarna. In this case the couple was on Shaman Chikitsa in the last 4 years, though menstrual cycle of female got regulated for some time yet the major issue of infertility was not resolved by Shaman Chikitsa alone. After planning Sansodhan for both partners followed by Vajikarana Chikitsa the couple achieved the conception. So, we can conclude that in case of infertility we can achieve better success rate if we follow the guideline mentioned by Charka i.e., Sansodhan followed by Vajikarna.

\section{REFERENCES}

1. Shusruta, Shusruta Samhita, Sharira Sthana, 2/33. Reprint edition. Varanasi: Surabharati Prakashana; reprint 2003.
2. Kalidas Tripathi, Harita Samhita with Hindi Commentary by Ramvalamba Shastri, Tritiya Khand, 48/1-6.Varanasi, 1985.

3. Agnivesha, Charaka Samhita, revised by Charaka and Dridhbala with Vidyotini Hindi commentary edited by Pt.Kashinath Shastri and Dr.Gorakhanatha Chaturvedi, Chaukhambha Sanskrit Sansthana, Gopal Mandir Lane, Varanasi, reprint 2013 Chikitsa Sthana 30/5.

4. Agnivesha, Charaka Samhita, revised by Charaka and Dridhbala with Vidyotini hindi commentary edited by Pt. Kashinath Shastri and Dr. Gorakhanatha Chaturvedi, Chaukhambha Sanskrit Sansthana, Gopal Mandir Lane, Varanasi, reprint 2013 Sutra Sthana 28/9-10.

5. Agnivesha, Charaka Samhita, revised by Charaka and Dridhbala with Vidyotini Hindi commentary edited by Pt. Kashinath Shastri and Dr. Gorakhanatha Chaturvedi, Chaukhambha Sanskrit Sansthana, Gopal Mandir Lane, Varanasi, reprint 2013 Sharira Sthana 2/30.

6. Agnivesha, Charaka Samhita, revised by Charaka and Dridhbala with Vidyotini Hindi commentary edited by Pt. Kashinath Shastri and Dr. Gorakhanatha Chaturvedi, Chaukhambha Sanskrit Sansthana, Gopal Mandir Lane, Varanasi, reprint 2013 Chikitsa Sthana 30/5.

7. Agnivesha, Charaka Samhita, revised by Charaka and Dridhbala with Vidyotini Hindi commentary edited by Pt. Kashinath Shastri and Dr. Gorakhanatha Chaturvedi, Chaukhabha Sanskrit Sansthana, Gopal Mandir Lane, Varanasi, reprint 2013 Chikitsa Sthana 2-1/50, 51.

8. Agnivesha, Charaka Samhita, revised by Charaka and Dridhbala with Vidyotini Hindi commentary edited by Pt.Kashinath Shastri and Dr.Gorakhanatha Chaturvedi, Chaukhambha Sanskrit Sansthana, Gopal Mandir Lane, Varanasi, reprint 2013 Sidhi Sthana 2/13.

9. Pandit Hemraja Sharma, Kashyapa Samhita, Vidyotini Hindi commentary, Chaukhambha Sanskrita Sansthana, Reprint 2018, Kalpa sthana 6/33 page no 390 .

\section{Cite this article as:}

Renu yadav, Soni Kapil, Anil Bhardwaj. Management of Bandhyatava (Infertility) By Sodhan Followed by Shaman Chikitsa: A Case Report. International Journal of Ayurveda and Pharma Research. 2021;9(7):35-40. https://doi.org/10.47070/ijapr.v9i7.1999

Source of support: Nil, Conflict of interest: None Declared

\section{*Address for correspondence Dr. Renu Yadav \\ PG Scholar, \\ Department of Prasuti Tantra Evum Stree Roga, Rajiv Gandhi Govt. Post Graduate Ayurvedic College \& Hospital, Paprola, Himachal Pradesh, India. Email: renuyadav228@gmail.com}

Disclaimer: IJAPR is solely owned by Mahadev Publications - dedicated to publish quality research, while every effort has been taken to verify the accuracy of the content published in our Journal. IJAPR cannot accept any responsibility or liability for the articles content which are published. The views expressed in articles by our contributing authors are not necessarily those of IJAPR editor or editorial board members. 